\title{
Het toepasselijk recht op gebundelde kartelschadeclaims
}

\author{
Van mozaïek tot Rubik's Cube
}

\author{
Mr.dr. L.M. van Bochove*
}

\begin{abstract}
Een internationale kartelschadevordering wordt beheerst door het recht van het land waar de markt is beïnloed. In de praktijk blijkt deze marktregel echter moeilijk toepasbaar, vooral wanneer vorderingen gebundeld worden ingediend. Dit artikel bespreekt de knelpunten van de marktregel en onderzoekt de praktische en juridische haalbaarheid van alternatieve aanknopingspunten.
\end{abstract}

\section{Inleiding}

De kartelschadeclaim is booming business. De afgelopen jaren is op dit terrein een heuse markt ontstaan, waarop aan de vraagzijde verschillende binnenlandse en buitenlandse professionele actoren actief zijn. Als litigation vehicles hebben zij zich toegelegd op het aankopen van individuele kartelschadevorderingen, om deze vervolgens gebundeld in rechte te innen. Deze ontwikkeling kan in belangrijke mate worden teruggevoerd op de Europese initiatieven om de privaatrechtelijke handhaving van het EU-mededingingsrecht ${ }^{1}$ te bevorderen. ${ }^{2}$ Voorlopig sluitstuk is de invoering van de Kartelschaderichtlijn ${ }^{3}$ in 2014 en de daaropvolgende implementatie in het nationale recht van de EU-lidstaten. ${ }^{4}$ De richtlijn beoogt een doeltreffende handhaving van het mededingingsrecht en gaat uit van volledige compensatie voor eenieder die schade heeft geleden als gevolg van een mededingingsinbreuk. ${ }^{5}$

Mr. dr. L.M. van Bochove is universitair docent Internationaal Privaatrecht aan de Universiteit Leiden.

1. Art. 101 en 102 VWEU.

2. Waaronder de erkenning door het Hof van Justitie van het recht op schadevergoeding bij een schending van het Europese mededingingsrecht, zie HvJ EG 20 september 2001, C-453/99, ECLI:EU:C:2001:465 (Courage/Crehan) en de publicatie van een Groenboek door de Europese Commissie in 2005, COM/2005/672.

3. Richtlijn 2014/104/EU van het Europees Parlement en de Raad van 26 november 2014 betreffende bepaalde regels voor schadevorderingen volgens nationaal recht wegens inbreuken op de bepalingen van het mededingingsrecht van de lidstaten van de Europese Unie.

4. In Nederland heeft de richtlijn geleid tot de invoering van afd. 3B 'Schending van mededingingsrecht' aan titel 3 van Boek 6 BW. Daarnaast is het Rv op een aantal punten gewijzigd, en is in dit wetboek afd. 1A 'Toegang tot bescheiden in zaken betreffende schending van mededingingsrecht' ingevoegd. Zie Implementatiewet richtlijn privaatrechtelijke handhaving mededingingsrecht, Stb. 2017, 28 .

5. Art. 3 Kartelschaderichtlijn.
Als gevolg van de richtlijn stemt het kartelschaderecht van de lidstaten inmiddels grotendeels overeen. ${ }^{6}$ Toch heeft de vraag welk recht van toepassing is op een grensoverschrijdende kartelschadevordering niet aan relevantie ingeboet. In veel zaken zal nog de oude, niet-geharmoniseerde wetgeving moeten worden toegepast, nu aan de nationale bepalingen ter implementatie van de materieelrechtelijke bepalingen van de Kartelschaderichtlijn geen terugwerkende kracht wordt toegekend. ${ }^{7}$ Bovendien blijven er grote verschillen bestaan tussen de rechtsregels van lidstaten en niet-lidstaten.

Zowel ondernemingen die deel hebben uitgemaakt van het kartel, als de door het kartel benadeelde partijen (concurrenten, directe en indirecte afnemers) hebben dus behoefte aan een duidelijk geformuleerde conflictregel om te kunnen bepalen welk recht van toepassing is op een kartelschadevordering die tegen of door hen is ingesteld. Uit prejudiciële vragen die de rechtbank Amsterdam in 2018 aan de Hoge Raad heeft gesteld, blijkt echter dat de vraag naar het toepasselijk recht op een kartelschadeclaim aanleiding geeft tot verschillende problemen en onduidelijkheden. Zo kan de toepassing van conflictregels leiden tot het onpraktische resultaat dat één vordering wordt beheerst door meerdere rechtsstelsels - de zogenaamde mozaiekbenadering. ${ }^{8}$ Ondanks het feit dat de Hoge Raad onvoldoende grond zag om de vragen van de rechtbank te beantwoorden, nu deze betrekking hadden op oud recht, ${ }^{9}$ zal deze kwestie de rechtspraktijk voorlopig nog wel bezig blijven houden. Niet alleen is al een reeks van vorderingen aanhangig gemaakt waarop de oude conflictregels (WCOD) van toepassing zijn, maar ook het huidige recht (Rome II) roept vragen op.

De vraag welk recht een internationale kartelschadeclaim beheerst, heeft wat weg van een Rubik's Cube: na enig gepuzzel is één kant van de kubus egaal van kleur, maar bij omkering blijkt dat de chaos aan een andere zijde alleen maar is toegenomen. Hetzelfde lijkt zich voor te doen bij het bepalen van het

6. De Kartelschaderichtlijn beoogt geen volledige harmonisatie te bewerkstelligen, waardoor zich alsnog verschillen kunnen voordoen.

7. Zie art. 22 lid 1 Kartelschaderichtlijn.

8. Rb. Amsterdam 17 januari 2018, ECLI:NL:RBAMS:2018:2040.

9. HR 16 maart 2018, ECLI:NL:HR:2018:345. 
toepasselijk recht op een vordering betreffende kartelschade: de keuze voor een bepaald aanknopingspunt kan het ene probleem oplossen en tegelijkertijd nieuwe moeilijkheden veroorzaken. Deze bijdrage beoogt de problematiek van de vaststelling van het toepasselijk recht ten aanzien van kartelschadeclaims naar oud en huidig conflictenrecht inzichtelijk te maken en onderzoekt mogelijke oplossingen op hun juridische én praktische haalbaarheid.

\section{Het toepasselijk recht op een kartelschadeclaim: juridisch kader}

De Kartelschaderichtlijn bevat geen regels inzake het toepasselijk recht in grensoverschrijdende zaken. Dit betekent dat de reguliere conflictenrechtelijke instrumenten van toepassing zijn om het toepasselijk recht op een kartelschadeclaim te bepalen. Aangezien de kartelschadevordering wordt aangemerkt als een niet-contractuele verbintenis, ${ }^{10}$ komen de Wet conflictenrecht onrechtmatige daad ${ }^{11}$ (WCOD) en de Verordening betreffende het recht dat van toepassing is op niet-contractuele verbintenissen ${ }^{12}$ (Rome II) in aanmerking.

\subsection{Oud recht: $W C O D$}

De WCOD regelt welk recht van toepassing is op verbintenissen die voortvloeien uit een kartel dat voor 11 januari 2009 tot stand is gekomen. De WCOD trad in werking per 1 juni 2001, maar aangenomen moet worden dat de wet slechts een codificatie vormt van het destijds geldende ongeschreven recht. $^{13}$

De hoofdregel van artikel 3 WCOD verwijst naar de lex loci delicti: het recht van de plaats waar de onrechtmatige daad plaatsvindt. Voor verbintenissen wegens ongeoorloofde mededinging - schendingen van mededingingswetgeving en oneerlijke concurrentie ${ }^{14}$ - is echter in artikel 4 een bijzondere regel opgenomen. Artikel 4 lid 1 WCOD bepaalt dat het recht van toepassing is van de staat op het grondgebied waarvan de mededingingshandeling de concurrentieverhoudingen beïnvloedt. Hoewel de wetgever bewust het woord 'markt' heeft vermeden, vanwege 'het bezwaar dat bij een voortschrijdende internationalisering van de handel "de markt" moeilijk valt te localiseren', ${ }^{15}$ wordt de conflictregel van artikel 4 lid 1 WCOD in de praktijk toch vaak aangeduid als 'marktregel'. ${ }^{16}$ In de memorie van toelichting merkt de minister op dat deze regel leidt tot een versnippering van het toepasselijk recht in het geval dat de concurrentieverhoudingen in meerdere staten

10. Vgl. HvJ EU 21 mei 2015, C-352/13, ECLI:EU:C:2015:335 (CDC/ Akzo), r.o. 43.

11. Stb. 2001,190

12. Verordening (EG) 864/2007 van het Europees Parlement en de Raad van 11 juli 2007, PbEG 2007, L 199/40.

13. Zie ook Rb. Amsterdam 1 mei 2019, ECLI:NL:RBAMS:2019:3393, r.o. 3.12 .

14. Kamerstukken II 1998/99, 26608, nr. 3, p. 8 (MvT).

15. Idem.

16. Zie o.a. Hof Arnhem-Leeuwarden 5 februari 2019, ECLI:NL:GHARL: 2019:1060, r.o. 5.5; Rb. Amsterdam 1 mei 2019, ECLI:NL:RBAMS: 2019:3393, r.o. 3.15 . zijn beïnvloed. ${ }^{17}$ De minister doelt hier op de mozaïekbenadering, ${ }^{18}$ die inhoudt dat de vordering conflictenrechtelijk wordt opgesplitst en dat het deel van de vordering dat betrekking heeft op de beïnvloede concurrentieverhoudingen in staat $\mathrm{A}$ wordt beheerst door het recht van staat $\mathrm{A}$, het deel dat ziet op de beïnvloeding van concurrentieverhoudingen in staat $\mathrm{B}$ door het recht van staat $\mathrm{B}$, enzovoort. De toepassing van deze benadering is veelal ingewikkeld, met name wanneer een groot aantal landen in het geding is, en kan daardoor nadelig uitwerken voor partijen (stijging van de kosten van de procedure) en de rechter (verhoging van de werklast).

Artikel 5 en 6 WCOD bieden de mogelijkheid om af te wijken van artikel 4 lid 1 WCOD en daarmee de nadelen van de mozaïekbenadering te omzeilen. Artikel 5 WCOD bevat een regel voor accessoire aanknoping: wanneer de onrechtmatige daad nauw verbonden is met een tussen dader en benadeelde bestaande of gewezen rechtsverhouding kan de rechter, in afwijking van artikel 4 lid 1 WCOD, het recht dat een andere rechtsverhouding beheerst, toepassen. De exceptie van artikel 5 WCOD ziet uitsluitend op gevallen van samenloop van rechtsverhoudingen; van een algemene exceptie ten gunste van een nauwer verbonden rechtsstelsel is geen sprake. Behalve de rechter kunnen ook de partijen zelf van de marktregel van artikel 4 lid 1 WCOD afwijken. Op grond van artikel 6 WCOD kunnen zij gezamenlijk een rechtskeuze uitbrengen. Deze bepaling biedt grote vrijheid aan de partijen: de keuze kan zowel vooraf als achteraf worden uitgebracht, ${ }^{19}$ en mag een 'neutraal' rechtsstelsel betreffen, dat geen band heeft met de daad van ongeoorloofde mededinging en/of partijen. Bovendien gelden geen strikte vormvereisten; de rechtskeuze is geldig wanneer zij uitdrukkelijk is gedaan of voldoende duidelijk blijkt uit de overeenkomst of omstandigheden van het geval.

\subsection{Huidig recht: Rome II}

Vorderingen met betrekking tot schade die voortvloeit uit een kartel dat op of na 11 januari 2009 is gevormd, vallen onder het temporele toepassingsgebied van Rome II. ${ }^{20}$

Volgens de hoofdregel van artikel 4 lid 1 Rome II is het recht van het land waar de schade intreedt (lex loci damni) van toepassing. In artikel 6 lid 3 Rome II zijn conflictregels opgenomen voor niet-contractuele verbintenissen die voortvloeien uit een beperking van de mededinging, waaronder inbreuken op zowel nationale als unitaire mededingingsregels worden verstaan. ${ }^{21}$ Volgens de Europese wetgever moet artikel 6 Rome II worden beschouwd als een verduidelijking van de hoofdregel en niet als uitzondering daarop. ${ }^{22}$

17. Kamerstukken II 1998/99, 26608, nr. 3, p. 8.

18. Asser/Kramer \& Verhagen 10-III 2015/1000.

19. Kamerstukken II 1998/99, 26608, nr. 3, p. 9 (MvT).

20. Zie art. 31 en 32 Rome II en HvJ EU 17 november 2011, C-412/10, ECLI:EU:C:2011:747 (Homawoo/GMF Assurances).

21. Zie overweging 22 van de considerans van Rome II.

22. Zie overweging 21 van de considerans van Rome II. 
Artikel 6 lid 3 sub a Rome II verwijst naar het recht van het land waarvan de markt daadwerkelijk of waarschijnlijk beïnvloed wordt. In de literatuur is gewezen op de identificatie- en lokalisatieproblemen die met het begrip 'relevante markt' gepaard gaan ${ }^{23}$ en die reden waren voor de Nederlandse wetgever om de term in de WCOD uit de weg te gaan. ${ }^{24}$ In deze bijdrage wordt, in lijn met de definitie van de Europese Commissie in het kader van het Unitaire mededingingsrecht ${ }^{25}$ en de meerderheidsopvatting in de literatuur, ${ }^{26}$ aangenomen dat de relevante markt moet worden bepaald aan de hand van zowel de relevante productmarkt ${ }^{27}$ als de relevante geografische markt. ${ }^{28,29}$ Voor de toepassing van artikel 6 lid 3 sub a Rome II moeten de gevolgen van een (mogelijke) beïnvloeding van de concurrentiewerking op deze markt voor de verschillende marktdeelnemers en hun afnemers worden gelokaliseerd. ${ }^{30}$

Wanneer de concurrentiewerking op de markt in verschillende landen is beïnvloed en de gelaedeerde de gevolgen hiervan in meerdere landen ondervindt, leidt de toepassing van artikel 6 lid 3 sub a Rome II, evenals artikel 4 lid 1 WCOD, tot een versnippering van het op de vordering toepasselijk recht. ${ }^{31}$ Anders dan de WCOD biedt Rome II in relatie tot kartelschadevorderingen geen mogelijkheid tot accessoire aanknoping. Bovendien bepaalt artikel 6 lid 4 Rome II dat partijen niet door middel van een rechtskeuze kunnen afwijken van het recht dat op grond van het derde lid van deze

23. Zie o.a. M. Hellner, Unfair competition and acts restricting free competition, Yearbook of Private International Law 2007, p. 60; W.-H. Roth, Internationales Kartelldeliktsrecht in der Rom II-Verordnung, in: D. Baetge, J. von Hein \& M. von Hinden (red.), Die richtige Ordnung. Festschrift für Jan Kropholler zum 70. Geburtstag, Heidelberg: Mohr Siebeck 2008, p. 642; A. Dickinson, The Rome II Regulation: The law applicable to non-contractual obligations, Oxford: Oxford University Press 2008, p. 420-423; J. Fitchen, Choice of law in international claims based on restrictions of competition: Article 6(3) of the Rome II Regulation, Journal of Private International Law 2009, afl. 2, p. 358-364.

24. Zie par. 2.1.

25. Bekendmaking van de Commissie inzake de bepaling van de relevante markt voor het gemeenschappelijke mededingingsrecht, PbEG 1997 , C $372 / 5$, nr. 9.

26. Zie o.a. Asser/Kramer \& Verhagen 10-III 2015/1025; Hellner 2007, p. 60-61.

27. De relevante productmarkt omvat volgens de Commissie 'alle producten en/of diensten die op grond van hun kenmerken, hun prijzen en het gebruik waarvoor zij zijn bestemd, door de consument als onderling verwisselbaar of substitueerbaar worden beschouwd'. Zie Bekendmaking, PbEG 1997, C 372/5, nr. 7.

28. Volgens de Commissie is de relevante geografische markt 'het gebied waarbinnen de betrokken ondernemingen een rol spelen in de vraag naar en het aanbod van goederen of diensten, waarbinnen de concurrentievoorwaarden voldoende homogeen zijn en dat van aangrenzende gebieden kan worden onderscheiden doordat daar duidelijk afwijkende concurrentievoorwaarden heersen'. Zie Bekendmaking, PbEG 1997, C $372 / 5$, nr. 8 .

29. In HvJ EU 5 juli 2018, C-27/17, ECLI:EU:C:2018:533 (flyLAL II), lijkt het Hof van Justitie in het kader van de bevoegdheid echter een afwijkend criterium te hanteren. Zie voor een uitgebreide en kritische analyse van dit arrest K.J. Saarloos, De plaats van het schadebrengende feit bij inbreuken op het mededingingsrecht, NIPR 2019, afl. 2, p. 393-394.

30. Roth 2008, p. 642.

31. Uitgebreid: Fitchen 2009, p. 357-358. bepaling van toepassing is. De reden voor de beperking van de partijautonomie moet worden gezocht in de omstandigheid dat niet alleen de belangen van de partijen in het geding zijn, maar dat met eerlijke, onbeperkte mededinging ook een publiek belang gemoeid is. Het zou daarom niet aan de partijen moeten worden overgelaten om te bepalen welk recht van toepassing is. ${ }^{32}$

Om de nadelen van de mozaiekbenadering (enigszins) te ondervangen, is in artikel 6 lid 3 sub b Rome II wel een beperkte rechtskeuzemogelijkheid opgenomen. Wanneer de markt in verschillende landen is beïnvloed, kan de gelaedeerde ervoor kiezen de gehele vordering te laten beheersen door het recht van de rechter, de lex fori. Deze eenzijdige rechtskeuze kan volgens bovengenoemde bepaling echter slechts worden uitgebracht wanneer (1) de rechter is aangezocht van de lidstaat waar de verweerder (of een van de verweerders) woonplaats heeft, (2) de markt van deze lidstaat rechtstreeks en aanzienlijk beïnloed is door de beperking van de mededinging, en (3) de gelaedeerde schadevergoeding vordert. Aangenomen moet worden dat nog een vierde, ongeschreven, toepassingsvereiste geldt: de gevolgen voor de gelaedeerde moeten zich hebben voorgedaan in verschillende landen, met inbegrip van het land van het forum. ${ }^{33}$ Ondervindt de gelaedeerde slechts in één land de gevolgen van de beïnvloeding van de concurrentiewerking op de markt, dan doen de problemen, die gepaard gaan met de mozaïekbenadering en waarvoor artikel 6 lid 3 sub b Rome II een oplossing beoogt te bieden, zich immers niet voor.

\section{Toepasselijk recht op gebundelde kartelschadevorderingen}

Uit bovenstaande analyse blijkt dat het niet altijd eenvoudig is om het toepasselijk recht op een individuele kartelschadeclaim te bepalen. De complicaties nemen alleen maar toe wanneer een litigation vehicle de vorderingen van een groot aantal gelaedeerden heeft overgenomen en deze gebundeld bij de rechter aanhangig maakt. In deze paragraaf wordt aan de hand van het feitencomplex dat ten grondslag lag aan twee recente uitspraken van de rechtbank Amsterdam onderzocht hoe het toepasselijk recht op gebundelde kartelschadevorderingen moet worden vastgesteld. De rechtbank beantwoordt deze vraag aan de hand van de conflictregels van de WCOD, die temporeel van toepassing is nu het kartel zich uitstrekte over de periode eind 1999 tot begin 2006. De toepassing van de bijzondere conflictregel van artikel 4 lid 1 WCOD blijkt

32. Zie ook Asser/Kramer \& Verhagen 10-III 2015/1028; Th.M. de Boer, Party autonomy and its limitations in the Rome II Regulation, in: A. Bonomi \& P. Volken (red.), Yearbook of private international law 2007, München: Sellier European Law Publishers 2008, p. 23. Zie voor kritiek op art. 6 lid 4 Rome II Fitchen 2009, p. 344-346; L.M. van Bochove, Internationaalprivaatrechtelijke aspecten van kartelschade, in: E.M. Hoogervorst e.a. (red.), Kartelschade, Deventer: Wolters Kluwer 2019, p. 224-226.

33. S. Francq \& W. Wurmnest, International antitrust claims under the Rome II Regulation, in: J. Basedow, S. Francq \& L. Idot (red.), International antitrust litigation, Oxford: Hart Publishing 2012, p. 127. 


\section{Maandblad \\ Ondernemingsrecht}

echter lastig, nu sprake is van een wereldwijd kartel. Bovendien zijn zowel de kartellisten als de gelaedeerden gevestigd in verschillende landen. Hieronder volgt een analyse van de argumentatie van de rechtbank Amsterdam, die uitmondt in de toepassing van de lex fori. Vervolgens wordt onderzocht welk recht op basis van Rome II van toepassing zal zijn.

\subsection{Luchtvaartkartelzaken: feiten en procesverloop}

Op 1 mei 2019 wees de rechtbank Amsterdam vonnis in twee kartelschadezaken tegen verschillende luchtvaartmaatschappijen, waaronder KLM, Lufthansa en Singapore Airlines. ${ }^{34}$ De procedures waren aanhangig gemaakt door Stichting Cartel Compensation (hierna: SCC), gevestigd in Den Haag, en het in Amsterdam gevestigde Equilib Netherlands B.V. (hierna: Equilib). SCC en Equilib zijn litigation vehicles die (vermeende) schadevorderingen van hun klanten door middel van cessie verkrijgen, om deze vervolgens gebundeld op eigen naam te innen.

De clientèle van zowel SCC als Equilib wordt gevormd door in verschillende landen gevestigde shippers: verzenders van goederen die via freight forwarders (expediteurs) luchtvrachtdiensten hebben afgenomen van de gedaagden. Deze shippers stellen schade te hebben geleden als gevolg van verboden afspraken betreffende brandstof- en veiligheidstoeslagen tussen een groot aantal luchtvaartmaatschappijen, waaronder alle gedaagden. Deelnemers aan dit luchtvaartkartel, dat duurde van december 1999 tot 14 februari 2006, werden in 2010 door de Europese Commissie beboet. ${ }^{35}$ Het besluit hiertoe werd in 2015 door het Gerecht van de Europese Unie nietig verklaard, ${ }^{36}$ waarna de Europese Commissie in maart 2017 een nieuw besluit uitvaardigde en de luchtvaartmaatschappijen beboette voor een totaalbedrag van bijna EUR 800 miljoen. ${ }^{37}$ Naar aanleiding van de boetebesluiten zijn verschillende civielrechtelijke zaken aanhangig gemaakt, zowel in Nederland als daarbuiten.

In de procedure die was ingesteld door SCC bij de rechtbank Amsterdam bleek de vaststelling van het toepasselijk recht op de kartelschadevorderingen zodanig ingewikkeld dat de rechtbank besloot ex artikel $392 \mathrm{Rv}$ prejudiciële vragen aan de Hoge Raad te stellen over de toepassing van de WCOD. ${ }^{38}$ De Hoge Raad zag echter af van beantwoording. Volgens de Hoge Raad was het onzeker of een antwoord op de vragen nodig was om op de vorderingen te beslissen, nu de inbreuk van de gedaagden op het Europese mededingingsrecht nog niet onherroepelijk was en ook nog niet vaststond waar de concurrentieverhoudingen zouden zijn beïnvloed. ${ }^{39}$ Daarnaast hadden de vragen betrekking op oud recht (de WCOD),

\footnotetext{
34. Rb. Amsterdam 1 mei 2019, ECLI:NL:RBAMS:2019:3392 en ECLI: NL:RBAMS:2019:3393.

35. Besluit van de Commissie van 9 november 2010, zaak COMP/39258.

36. Zie o.a. Gerecht EU 16 december 2015, T-67/11, ECLI:EU:T:2015:984 (Martinair Holland NV/Commissie).

37. Besluit van de Commissie van 17 maart 2017, zaak AT.39258.

38. Rb. Amsterdam 17 januari 2018, ECLI:NL:RBAMS:2018:2040.

39. HR 16 maart 2018, ECLI:NL:HR:2018:345, r.o. 3.4.2.
}

waardoor het voor de Hoge Raad niet vaststond dat beantwoording rechtstreeks van belang is 'voor een veelheid aan vorderingsrechten die gegrond zijn op dezelfde of soortgelijke feiten en uit dezelfde of soortgelijke samenhangende oorzaken voortkomen', zoals artikel 392 lid 1 Rv vereist. ${ }^{40}$

\subsection{Toepasselijk recht op grond van WCOD}

Omdat de Hoge Raad geen uitsluitsel bood over de juiste toepassing van de WCOD, moest de rechtbank Amsterdam zelf aan de slag. Al eerder had de rechtbank in een tussenvonnis overwogen dat het toepasselijk recht per vordering moet worden vastgesteld; dat deze door middel van cessie in handen waren gekomen van een litigation vehicle en als bundel waren ingediend, doet hier niet aan af. ${ }^{41}$

Vervolgens moest de rechtbank beslissen wat het relevante aanknopingspunt is om het toepasselijk recht op deze verschillende vorderingen te bepalen. De luchtvaartmaatschappijen betoogden dat 'de staat waar de mededingingshandeling de concurrentieverhoudingen beïnloed heeft' in de zin van artikel 4 lid 1 WCOD de staat is waar zich de luchthaven van vertrek bevindt. Hier zouden de onderhandelingen betreffende de condities voor de luchtvrachtdienst met de freight forwarders doorgaans plaatsvinden, en hier zouden ook de noodzakelijke formaliteiten voor deze dienst moeten worden voltooid. Volgens de luchtvaartmaatschappijen zou de hantering van dit aanknopingspunt bovendien leiden tot voorspelbare uitkomsten. Als praktisch voordeel werd genoemd dat eventuele vorderingen van de freight forwarders steeds door hetzelfde recht worden beheerst als die van de shippers. ${ }^{42}$ Bovendien zou dit aanknopingspunt in lijn zijn met eerdere rechtspraak: in verband met het paraffinewaskartel ${ }^{43}$ en het natriumchloraatkartel ${ }^{44}$ hadden de rechtbank Den Haag en de rechtbank Amsterdam immers bepaald dat de concurrentieverhoudingen zijn beïnvloed op de plaats waar vraag en aanbod samenkomen - volgens de rechtbank in die zaken de plaats waar de feitelijke afname van de producten plaatsvond. Bij het luchtvaartkartel is de plaats van afname echter aanzienlijk minder gemakkelijk vast te stellen. De afname van een luchtvrachtdienst kan zowel worden gelokaliseerd op de luchthaven van vertrek als op die van aankomst en 'in de lucht op alle plaatsen van de vluchtroute'. ${ }^{45}$ Volgens de rechtbank heeft het onderhavige kartel wereldwijd de concurrentieverhoudingen beïnvloed, waardoor op grond van artikel 4 lid 1 WCOD 'ieder denkbaar rechtsstelsel van toepassing zou kunnen zijn' ${ }^{46}$

40. HR 16 maart 2018, ECLI:NL:HR:2018:345, r.o. 3.4.3.

41. Rb. Amsterdam 2 augustus 2017, ECLI:NL:RBAMS:2017:10662, r.o. 4.9.

42. Rb. Amsterdam 2 augustus 2017, ECLI:NL:RBAMS:2017:10662, r.o. 4.2; Rb. Amsterdam 1 mei 2019, ECLI:NL:RBAMS:2019:3393, r.o. 3.7.

43. Rb. Den Haag 17 december 2014, ECLI:NL:RBDHA:2014:15722 (CDC/Shell), r.o. 4.49 .

44. Rb. Amsterdam 10 mei 2017, ECLI:NL:RBAMS:2017:3166 (CDC/ Kemira), r.o. 4.24 .

45. Rb. Amsterdam 1 mei 2019, ECLI:NL:RBAMS:2019:3393, r.o. 3.18.

46. Rb. Amsterdam 1 mei 2019, ECLI:NL:RBAMS:2019:3393, r.o. 3.15. 
Ook alternatieve aanknopingspunten werden door de rechtbank ongeschikt geacht. Aanknoping bij de vestigingsplaats van de luchtvaartmaatschappijen heeft als belangrijk nadeel dat kartellisten de mogelijkheid zouden hebben om door middel van het kiezen van hun vestigingsplaats te bewerkstelligen welk recht van toepassing is op een kartelschadevordering, en daarmee zouden kunnen kiezen voor een rechtsstelsel waarin het maken van prijsafspraken niet als onrechtmatig wordt beschouwd. ${ }^{47}$ De rechtbank overwoog dat er ook bezwaren kleven aan de aanknoping bij de vestigingsplaats van de gelaedeerden. In de eerste plaats zou deze aanknoping ertoe leiden dat de rechtbank - vanwege de bundeling van de vorderingen - in de onderhavige procedure een groot aantal rechtsstelsels moet toepassen. Ten tweede zou deze aanknoping ertoe leiden dat in de procedures die aanhangig zijn gemaakt door freight forwarders een ander rechtsstelsel wordt toegepast dan in de procedures van de shippers, hetgeen kan leiden tot verschillende uitkomsten. ${ }^{48}$

De rechtbank Amsterdam zag uiteindelijk geen heil in de toepassing van artikel 4 lid 1 WCOD en koos voor een praktische oplossing. $\mathrm{Nu}$ ook in Nederland de concurrentieverhoudingen door het kartel waren verstoord, meende de rechtbank dat Nederlands recht als de lex fori kan worden toegepast. Volgens de rechtbank werd de toepassing van Nederlands recht op alle vorderingen gerechtvaardigd door het doeltreffendheidsbeginsel en de goede procesorde. ${ }^{49}$

\subsection{Toepasselijk recht op grond van Rome II}

\subsubsection{Aanknoping bij vestigingsplaats van de indirecte afnemers}

Op het eerste gezicht lijkt de marktregel van artikel 6 lid 3 sub a Rome II in het onderhavige geval op dezelfde problemen te stuiten als artikel 4 lid 1 WCOD. ${ }^{50}$ Het luchtvaartkartel heeft immers wereldwijd impact gehad, waardoor aanknoping bij de beïnloede markt zou leiden tot een enorme versnippering van het toepasselijk recht. In paragraaf 2.2 werd echter gesteld dat het criterium 'beïnvloede markt' uit artikel 6 lid 3 sub a Rome II betrekking heeft op de gevolgen voor de gelaedeerden van de beïnvloeding van de concurrentiewerking op de markt. Door de plaats waar de gevolgen zich voordoen als aanknopingspunt te nemen wordt het aantal potentieel toepasselijke rechtsstelsels aanzienlijk gereduceerd. Om het toepasselijk recht te kunnen bepalen, moeten twee vervolgvragen worden beantwoord: wat zijn de relevante gevolgen en waar moeten deze worden gelokaliseerd?

Een kartel kan gevolgen hebben voor verschillende marktdeelnemers, waarbij volgens de Europese Commissie de indirecte afnemers, en niet de concurrenten of de directe afnemers, veelal het meest te lijden hebben onder inbreuken van het

47. Rb. Amsterdam 1 mei 2019, ECLI:NL:RBAMS:2019:3393, r.o. 3.19.

48. Rb. Amsterdam 1 mei 2019, ECLI:NL:RBAMS:2019:3393, r.o. 3.21.

49. Rb. Amsterdam 1 mei 2019, ECLI:NL:RBAMS:2019:3393, r.o. 3.24

50. Zie par. 3.2. mededingingsrecht. ${ }^{51}$ De gevolgen van het kartel voor de gelaedeerden kunnen uiteenlopen: verlies van marktaandeel, maar ook hogere kosten door het moeten betalen van een kunstmatig hoge prijs. Hoewel de rechtbank Amsterdam opmerkte dat het kartel voor een individuele shipper tot verschillende schadeposten kan leiden, ${ }^{52}$ moet worden aangenomen dat de gevolgen van het kartel voor de shippers primair bestaan in het betalen van meerkosten wegens kunstmatig hoge prijzen. ${ }^{53}$

Waar moeten deze gevolgen vervolgens worden gelokaliseerd? In het kader van de Europese bevoegdheidsregels heeft het Hof van Justitie in het arrest CDC/Akzo ${ }^{54}$ bepaald dat schade bestaande in meerkosten die zijn betaald wegens een kunstmatig hoge prijs in beginsel intreedt op de plaats waar de gelaedeerde is gevestigd. ${ }^{55}$ Het is aannemelijk - ook met het oog op de vereiste consistentie tussen Rome II en Brussel I-bis ${ }^{56}$ - dat voor het toepasselijk recht op een kartelschadevordering hetzelfde geldt. Een complicerende factor is dat de shippers indirecte afnemers zijn; de meerkosten waarmee zij geconfronteerd worden, zijn aan hen doorberekend door de freight forwarders, die de luchtvrachtdiensten op hun beurt van de kartellisten hebben afgenomen.

Het is verleidelijk om de gevolgen van het kartel voor indirecte afnemers, bestaande in doorberekende meerkosten, te kwalificeren als 'indirecte gevolgen', die vervolgens - in lijn met artikel 4 lid 1 Rome $\mathrm{II}^{57}$ - niet relevant worden geacht voor het bepalen van het toepasselijk recht. Het relevante aanknopingspunt voor het toepasselijk recht op de vordering van de indirecte afnemer is in deze opvatting de plaats waar de directe afnemer de gevolgen ondervindt van het kartel..$^{58}$ In de onderhavige zaak zou dat betekenen dat de kartelschadevordering van de shipper wordt beheerst door het recht van het land waar de freight forwarder gevestigd is.

51. Witboek betreffende schadevergoedingsacties wegens schending van de communautaire mededingingsregels, COM/2008/165 def., p. 9.

52. Rb. Amsterdam 1 mei 2019, ECLI:NL:RBAMS:2019:3393, r.o. 3.13.

53. In de rechtseconomische literatuur wordt gewezen op het volume effect: wanneer de meerkosten (gedeeltelijk) worden doorberekend aan klanten, dan kan dit leiden tot een verlies van afzet en daarmee tot winstverlies. Zie over het volume effect onder meer G. Niels \& R. Noble, Quantifying antitrust damages - Economics and the law, in: K. Hüschelrath \& H. Schweitzer (red.), Public and private enforcement of competition law in Europe, Berlijn: Springer 2014, p. 127-128. Voornoemd afzetverlies moet mijns inziens als gevolgschade worden gekwalificeerd, die niet relevant is bij de bepaling van het toepasselijk recht.

54. HvJ EU 21 mei 2015, C-352/13, ECLI:EU:C:2015:335.

55. HvJ EU 21 mei 2015, C-352/13, ECLI:EU:C:2015:335, r.o. 52.

56. Zie overweging 7 bij de considerans van Rome II.

57. Art. 4 lid 1 Rome II luidt: 'Tenzij in deze verordening anders bepaald, is het recht dat van toepassing is op een onrechtmatige daad het recht van het land waar de schade zich voordoet, ongeacht in welk land de schadeveroorzakende gebeurtenis zich heeft voorgedaan en ongeacht in welke landen de indirecte gevolgen van die gebeurtenis zich voordoen [curs. LvB].'

58. Zie over deze optie R. Plender \& M. Wilderspin, The European private international law of obligations, Londen: Sweet \& Maxwell 2015, nr. 20-062 e.v. 
Recentelijk heeft het Hof van Justitie echter in het TiborTrans-arrest, ${ }^{59}$ wederom in het kader van bevoegdheid, overwogen dat de schade van een indirecte afnemer, bestaande in meerkosten die het gevolg zijn van een artificieel hoge prijs, moet worden aangemerkt als 'rechtstreekse schade'. De plaats van de beïnvloede markt is volgens het Hof van Justitie 'de plaats waar de prijzen op de markt zijn vervalst, en waar de benadeelde [de indirecte afnemer; LvB] stelt schade te hebben geleden'. ${ }^{60}$ Daarmee zal de rechter van de plaats waar de indirecte afnemer is gezeteld, in beginsel bevoegd zijn om van diens vordering kennis te nemen. In Tibor-Trans overwoog het Hof van Justitie dat zijn uitleg van het begrip 'plaats waar de schade is ingetreden' in overeenstemming is met artikel 6 lid 3 sub a Rome II. ${ }^{61}$ In het kader van de luchtvaartkartelzaken leidt de analoge toepassing van Tibor-Trans en CDC/ Akzo op voornoemd artikel mijns inziens tot de volgende uitkomsten:

1. De schade van de shipper, bestaande in het betalen van de door de freight forwarder doorberekende meerkosten, moet worden gekwalificeerd als een direct gevolg van het luchtvaartkartel.

2. De 'beïnvloede markt' in de zin van artikel 6 lid 3 sub a Rome II moet, nu sprake is van een wereldwijd kartel, worden gelokaliseerd op de plaats waar de shipper stelt zijn schade te hebben geleden, dat wil zeggen waar hij is gevestigd.

Dit betekent dat de kartelschadevordering van de shipper ingevolge artikel 6 lid 3 sub a Rome II wordt beheerst door het recht van het land waar hij gevestigd is. ${ }^{62}$

\subsubsection{Bezwaren en alternatieve oplossingen}

Aan de aanknoping bij de vestigingsplaats van de shipper zijn echter, zoals de rechtbank Amsterdam al aangaf, nadelen verbonden. Het eerste nadeel is dat de gebundelde vorderingen van shippers die in verschillende landen zijn gevestigd door verschillende rechtsstelsels worden beheerst. Gezien de rechtspraak van het Hof van Justitie in het kader van de Europese bevoegdheidsregels ${ }^{63}$ moet worden angenomen dat de overdracht van schuldvorderingen door de schuldeiser, gelijk aan het commune recht, geen invloed kan hebben op de bepaling van het op de vordering toepasselijk recht op grond van artikel 6 lid 3 Rome II. Het toepasselijk recht moet dus voor elke vordering afzonderlijk worden bepaald. De rechtskeuzemogelijkheid van artikel 6 lid 3 sub b Rome II biedt geen uitkomst, aangezien het probleem hier wordt gevormd door het feit dat er meerdere gelaedeerden zijn, die in verschillende staten zijn gevestigd. Bovendien zal de schade die zij hebben geleden doorgaans worden gelokaliseerd in één land: dat van hun zetel.

59. HvJ EU 29 juli 2019, C-451/18, ECLI:EU:C:2019:635.

60. HvJ EU 29 juli 2019, C-451/18, ECLI:EU:C:2019:635, r.o. 37.

61. HvJ EU 29 juli 2019, C-451/18, ECLI:EU:C:2019:635, r.o. 37.

62. In lijn met art. 23 lid 1 Rome II zal in beginsel moeten worden aangeknoopt bij de hoofdvestiging van de rechtspersoon.

63. Zie o.a. HvJ EU 18 juli 2013, C-147/12, ECLI:EU:C:2013:490 (ÖFAB), r.o. 58 en HvJ EU 21 mei 2015, C-352/13, ECLI:EU:C: 2015:335 (CDC/Akzo), r.o. 35.
Een tweede onwelkome implicatie is dat artikel 6 lid 3 sub a Rome II ertoe kan leiden dat de vordering van de shipper door een ander recht wordt beheerst dan die van de freight forwarder, die het vervoer van de shipper heeft georganiseerd. Dit zou kunnen leiden tot verschillende uitkomsten, bijvoorbeeld als het ene rechtsstelsel wel en het andere geen 'passing-on'-verweer accepteert in verband met doorberekende schade. ${ }^{64}$ Hoewel de Kartelschaderichtlijn dit laatste probleem voor de toekomst grotendeels heeft opgelost door de lidstaten ertoe te verplichten de mogelijkheid tot het voeren van een doorberekeningsverweer in hun nationale wetgeving op te nemen, ${ }^{65}$ blijft het risico aanwezig wanneer (1) de vorderingen worden beheerst door het oude recht (preharmonisatie) of (2) op een van de vorderingen het recht van een niet-lidstaat van toepassing is.

De praktische oplossing van de rechtbank Amsterdam om, vanwege het doeltreffendheidsbeginsel en de goede procesorde, op alle kartelschadevorderingen de lex fori toe te passen, zal in het kader van Rome II niet voorhanden zijn. De ruimte voor rechterlijke discretie is in Rome II, anders dan in de WCOD, vrijwel nihil. ${ }^{66}$ Dit geldt nog sterker voor artikel 6 lid 3 Rome II, dat - anders dan bijvoorbeeld artikel 4 Rome II - geen exceptie kent op grond waarvan een kennelijk nauwer verbonden rechtsstelsel kan worden toegepast.

Rome II biedt dus geen mogelijkheid om steeds hetzelfde recht toe te passen op gebundelde kartelschadevorderingen. Het nadeel dat de vorderingen van shipper en freight forwarder mogelijk door verschillende rechtsstelsels worden beheerst, kan echter wel worden ondervangen, namelijk door voor de vordering van de shipper aan te knopen bij het recht dat de vordering beheerst van diens wederpartij, de freight forwarder. ${ }^{67}$ De gevolgen van de shipper als indirecte afnemer zouden dan worden gekwalificeerd als 'indirecte gevolgen', die niet relevant zijn voor het bepalen van het toepasselijk recht. Met het oog op de beoogde consistentie tussen Europese IPRinstrumenten is deze oplossing niet ideaal; zij wijkt immers af van de uitleg die het Hof van Justitie in het Tibor-Trans-arrest heeft gegeven aan de Brussel I-bis-Verordening. Daar staat tegenover dat een coherente uitleg er niet toe kan leiden dat een begrip wordt geïnterpreteerd op een wijze die niet strookt met het stelsel en de doelstellingen van de verordening. ${ }^{68} \mathrm{Het}$ belang om de kartelschadeclaims van de directe afnemer en de indirecte afnemer aan hetzelfde rechtsstelsel te onderwerpen zou, ook met het oog op een efficiënte afwikkeling van de vorderingen, een rechtvaardiging kunnen opleveren voor een divergerende uitleg van artikel 6 lid 3 Rome II. ${ }^{69}$

64. Rb. Amsterdam 1 mei 2019, ECLI:NL:RBAMS:2019:3393, r.o. 3.21.

65. Art. 13 Kartelschaderichtlijn.

66. Zie ook T.C. Hartley, Choice of law for non-contractual liability: Selected problems under the Rome II Regulation, The International and Comparative Law Quarterly 2008, afl. 4, p. 908.

67. Vgl. Plender \& Wilderspin 2015, nr. 20-069.

68. HvJ EU 16 januari 2014, C-45/13, ECLI:EU:C:2014:7 (Kainz/Patherwerke), r.o. 20.

69. Vgl. Plender \& Wilderspin 2015, nr. 20-069. 


\section{Conclusie}

Zowel onder de WCOD als onder Rome II blijkt het vaststellen van het toepasselijk recht op een schadevordering die voortvloeit uit een wereldwijd kartel een juridische Rubik's Cube. De puzzel wordt nog gecompliceerder wanneer vorderingen gebundeld worden ingediend.

De praktische oplossing van de rechtbank Amsterdam om in de luchtvaartkartelzaken op alle vorderingen de lex fori toe te passen valt vanuit het oogpunt van doelmatigheid te rechtvaardigen. Onder Rome II staat deze mogelijkheid echter niet open; de conflictregels van dit instrument bieden de rechter daartoe geen ruimte. Gezien de Europese jurisprudentie over bevoegdheid lijkt te moeten worden aangeknoopt bij de plaats van vestiging van de benadeelde, ongeacht of deze benadeelde een directe of indirecte afnemer van een kartellist is. De keuze voor dit aanknopingspunt heeft als voordeel dat elke vordering wordt beheerst door één rechtsstelsel, waardoor de onhandzame mozaïekbenadering wordt ontweken. Daar staat tegenover dat zij ertoe kan leiden dat de vorderingen van directe en indirecte afnemers door verschillende rechtsstelsels worden beheerst, wat de afwikkeling van de schade zou kunnen bemoeilijken. Een andere mogelijkheid is om voor het toepasselijk recht op de vordering van de indirecte afnemer aan te knopen bij de vestigingsplaats van de directe afnemer.

Beide opties hebben als nadeel dat zij geen oplossing bieden voor een efficiënte afhandeling van gebundelde kartelschadeclaims. Daar komt bij dat - gezien het universele formele toepassingsgebied van Rome II $^{70}$ - de vordering van een benadeelde die buiten de EU is gevestigd, wordt beheerst door het recht van een niet-EU-lidstaat. Mogelijk biedt dat recht minder mogelijkheden tot schadeverhaal dan het recht van de EUlidstaten, die alle de Kartelschaderichtlijn hebben geïmplementeerd. Dit zou een negatief effect kunnen hebben op de privaatrechtelijke handhaving van de Europese antitrustregels of de nationale mededingingswetgeving van de lidstaten.

Bij een herziening van Rome II verdienen de hierboven gesignaleerde kwesties volle aandacht. Het op Europees niveau invoeren van een lex fori-regel voor kartelschadezaken zou veel problemen ondervangen. Verwijzing naar het nationale recht van de rechter wordt echter doorgaans vermeden, omdat zij de beoogde beslissingsharmonie in de EU kan ondergraven. ${ }^{71}$ Het antwoord op de vraag welk recht van toepassing is, hangt dan immers af van in welke lidstaat wordt geprocedeerd, wat niet bijdraagt aan de rechtszekerheid. Dit bezwaar valt echter (grotendeels) weg wanneer de kartelschadezaak valt onder het temporele toepassingsgebied van de Kartelschaderichtlijn. Voor de uitkomst van een geschil zou het dan weinig verschil

70. Art. 3 Rome II.

71. Zie overweging 6 bij de considerans van Rome II: 'De goede werking van de interne markt vereist, ter bevordering van de voorspelbaarheid van de uitslag van rechtsgedingen, de rechtszekerheid en het vrije verkeer van vonnissen, dat de in de lidstaten geldende collisieregels hetzelfde nationale recht aanwijzen, ongeacht bij welke rechter het geding aanhangig wordt gemaakt.' moeten maken of de Nederlandse, de Duitse of de Hongaarse rechter zijn eigen kartelschadewetgeving toepast, aangezien het recht in alle lidstaten in hoge mate geharmoniseerd is. 